\title{
Variability, Heritability and Genetic Advance in Chrysanthemum (Chrysanthemum morifolium Ramat.) under Ecological Conditions of Sub-Humid Zone of Rajasthan
}

\author{
Sushma Patil*, Kamal Kishor Nagar and D.A. Sumana
}

Department of Floriculture and Landscaping, College of Horticulture and Forestry, Jhalarapatan, Jhalawar- (Agriculture University, Kota) 326023 (Rajasthan), India

*Corresponding author

\begin{abstract}
A B S T R A C T
\section{Keywords}

Chrysanthemum, Genetic advance, Genetic variability, Heritability

Article Info

Accepted:

15 January 2019

Available Online:

10 February 2019

Studies on genetic variability, heritability and genetic advance were carried out among 15 genotypes of chrysanthemum for characters to identify genotypes to be used in breeding programme. High PCV and GCV was recorded in fresh flower weight (GCV \%: 69.92, PCV\%: 70.25) indicate the existence of wide range of genetic variability and hence there is a good scope for the improvement of these characters through selection. High heritability with high genetic advance as per cent mean was recorded in number of leaves per plant, leaf area, number of cut flowers per plant indicating the additive gene action of these characters. Exploitation of the additive variance would be possible by simple selection procedures and the mean of the trait could be shifted in a positive and desired direction. High heritability with moderate genetic advance as per cent of mean recorded in plant height $(90.72 \%)$, flower diameter and days to flower bud appearance indicating the nonadditive component of variance for the character, which will not give the desirable results by simple selection.
\end{abstract}

\section{Introduction}

Chrysanthemum (Chrysanthemum morifolium Ramat.) is a multi-use flower crop belonging to Asteraceae family, and gaining more popularity as a cut flower for interior decoration and in bouquets. It is a highly attractive and charming flowering plant, having number of varieties in the world is reported to be above 2000 (Joshi et al., 9). It is the second largest cut flower after rose among the ornamental plants. Several species of chrysanthemum are ornamental and grown in gardens for their large, showy, multi colored flowers (Anon).

In India, due to research on genetic improvement at different institutions, approximately one thousand varieties have been developed. In spite of wide range of variability, very little attention has been paid for its improvement. There is a need for identification of varieties suitable for growing in different agro climatic conditions for 
specific purposes. Information on the nature and magnitude of variability present in the existing material and association among the various characters is pre-requisite for any breeding programme for high yield and quality. Flower yield, a complex character, is not only influenced by its associated characters but also are governed by number of genes, and environment. For effective selection, it is necessary to separate genetic variability from total variability, which enables breeders to adopt suitable breeding programmes. The assessment of genetic variability is necessary to evaluate the performance of the individual cultivars. The analysis of variance permits estimation of phenotypic and genotypic co-efficient of variability of various polygenic traits. The genotypic co-efficient of variation measures the extent of variability among the different traits caused due to the inherent capacity of genotype. The genotypic and phenotypic coefficient of variation are needed to understand the effect of environment on various polygenic traits (Allard, 1960). The aim of present study was to understand the nature and extent of variability present in a set of ten genotypes and to identify elite genotypes to be used in hybridization programme to bring about desired improvement for crop yield.

\section{Materials and Methods}

The present investigation was carried out during July, 2016 to February, 2017 at the Instructional Farm, Department of Floriculture and Landscaping, College of Horticulture and Forestry, Jhalarapatan city, Jhalawar (Agriculture University, Kota) in order to study the most suitable varieties of standard chrysanthemum for flowering characters. The experimental site was geographically located at $23^{0} 4^{\prime}$ to $24^{0} 52^{\prime} \mathrm{N}$ Latitude and $75^{\circ} 29^{\prime}$ to $76^{\circ} 56^{\prime}$ E-Longitude in the South-Eastern Rajasthan. Agroclimatically, the district falls in Zone $-\mathrm{V}$ known as Humid South- Eastern Plain of Rajasthan. The experiment was carried out to evaluate the performance of fifteen varieties viz., 'BC-1-123', 'Shova', 'Accession No24', 'Pink Cloud', 'Lalima', 'Jaya', 'Bravo', 'Ravikiran', 'Jafri', 'Shyamal','White Star', 'Thai Chung Queen', 'PusaKesari', 'Pusa Arunodaya', 'Pusa Chitraksha' in RBD design with three replications. The rooted cuttings were dipped with Bavistin @ 0.2\% before planting then planted at a spacing of 40 $\mathrm{cm}$ X $40 \mathrm{~cm}$. Recommended package of practices was employed to obtain satisfactory plant growth. Adequate measures were taken to prevent lodging by staking the plants and disbudding and dishooting also carried out. Data on number of cut flowers per plant, flower diameter $(\mathrm{cm})$, fresh flower weight $(\mathrm{g})$, stalk length $(\mathrm{cm})$, stalk diameter $(\mathrm{cm})$, vase life (days), in-situ life (days), flower colour and type of the flower recorded on five randomly selected plants in each variety. The data was analyzed at $5 \%$ level of significance statistically. The vase life and in-situ life of flowers were measured upto the colour fading of the flowers.

\section{Results and Discussion}

The estimated values of genotypic coefficient of variation, phenotypic coefficient of variation, environmental coefficient of variation, heritability and genetic advance as per cent mean were presented in the Table 1. The varieties exhibited the significant variation among all the different characters studied. The phenotypic coefficient variation values of different parameters were higher than the genotypic coefficient of variation of different parameters studied in the present field experiment.

\section{Plant height (cm)}

The phenotypic, genotypic and environmental coefficient of variation of plant height was 
$21.41 \%, 20.40 \%$ and $6.52 \%$ respectively. The recorded heritability and genetic advance mean per cent was 90.72 and 40.02, respectively.

\section{Plant spread (cm)}

The data given in Table 1 presents that the plant spread of about $(21.65 \%, 19.89 \%$ and $8.55 \%)$ of the phenotypic, genotypic and environmental coefficient of variation respectively.

It also presents the heritability $(84.41 \%)$ and genetic advance mean was (37.64 \%).

\section{Numbers of leaves per plant}

The data revealed that the numbers of leaves per plant was significantly varied and recorded $(94.08 \%)$ of heritability, phenotypic coefficient of variation $(33.93 \%)$, genotypic coefficient of variation $(32.91 \%)$, environmental coefficient of variation $(8.26 \%)$ and it has genetic advance mean value of about $(65.76 \%)$.

\section{Stem thickness (cm)}

Stem thickness recorded (77.67\%) of heritability and genetic advance mean per cent was of about (32.98\%). The genotypic coefficient of variation (18.16\%), phenotypic coefficient of variation (20.61\%), environmental coefficient variation $(9.74 \%)$.

\section{Leaf area $\left(\mathrm{cm}^{2}\right)$}

Leaf area has evident of about $46.83 \%$ phenotypic coefficient of variation $46.10 \%$ genotypic coefficient of variation and 8.23\% environmental coefficient variation with a heritability of $96.91 \%$.

It also evident that leaf area had genetic advance mean with (93.49\%).

\section{Days to flower bud appearance}

The data which is given in the Table 1 presents that higher phenotypic coefficient of variation $(12.42 \%)$ than the genotypic coefficient of variation $(11.82 \%)$ and $(3.84 \%)$ environmental coefficient variation. It has moderate $(90.45 \%)$ heritability and low genetic advance mean $(23.15 \%)$.

\section{Days to full boom}

The days to full bloom exhibited the significant variation among the varieties which showed the $83.39 \%$ of heritability and genetic advance as per cent mean (16.42\%). The phenotypic, genotypic and environmental coefficient of variation was $(9.56 \%, 8.73 \%$ and $3.90 \%$ ) respectively.

\section{Numbers of cut flowers per plant}

The data of number of cut flowers per plant exhibited highest heritability (95.93\%) and genetic advance per cent mean was $(67.86 \%)$. In this character the varieties were significantly varied whereas it exhibited the (34.34\%, 33.63\%, \& 6.93\%) phenotypic, genotypic and environmental coefficient of variation respectively.

\section{Numbers of cut flowers per plot}

As it is estimated value of numbers of cut flowers per plot so it exhibited similar variability $(34.34 \% \mathrm{PCV}, 33.63 \% \mathrm{GCV}$, $6.93 \%$ ECV), heritability $(95.93 \%)$ and genetic advance as per cent mean (67.86) compare to numbers of cut flowers per plant.

\section{Fresh flower weight (g)}

The character fresh flower weight presented higher heritability of about (99.08\%) compared to other characters. The variability is significant among different varieties which 
recorded the $(70.25 \%, 69.92 \% \& 6.75 \%)$ phenotypic, genotypic and environmental coefficient of variation whereas, fresh flower weight recorded highest genetic advance mean $143.37 \%$. compared to other characters.

\section{Flower yield per plant (g)}

The flower yield per plant recorded phenotypic, genotypic and environmental coefficient of variation, heritability and genetic advance mean $(63.76 \%, 62.20 \%$, $14.03 \%, 95.16 \%$, and $124.99 \%$, respectively).

\section{Flower yield per plot (g)}

Flower yield per plot presented the significant variation among the varieties and recorded of about genotypic coefficient of variation (62.21\%), phenotypic coefficient of variation $(63.76 \%)$, moderate heritability $(95.16 \%)$ and genetic advance as per cent mean (125.01).

\section{Flower diameter (cm)}

The varieties where significantly varied for the character flower diameter.

The data given in the Table 1 presented the highest heritability (94.13\%), phenotypic coefficient of variation (25.36\%), genotypic coefficient of variation $(24.61 \%)$, environmental coefficient of variation $(6.14 \%)$ and genetic advance mean (49.18\%).

\section{Stalk length $(\mathrm{cm})$}

The stalk length exhibited that (67.01) of genetic advance as per cent mean with heritability $(96.75 \%)$, phenotypic coefficient of variation $(33.62 \%)$, genotypic coefficient of variation $(33.07 \%)$ and environmental coefficient of variation $(6.06 \%)$.

The varieties were significantly varied for the character of stalk length.

\section{Stalk diameter $(\mathbf{c m})$}

The phenotypic coefficient of variation, genotypic coefficient of variation, environmental coefficient variation, heritability, genetic advance as per cent mean for stalk diameter are $(46.58 \%, 45.99 \%$, $7.41 \%, 97.47 \%, 93.53$, respectively) and the stalk diameter were significantly varied among the varieties.

\section{Numbers of ray florets}

The trait numbers of ray florets had a highest heritability among all the traits of about $(99.07 \%)$. The other values like phenotypic, genotypic, environmental coefficient of variation and genetic advance as per cent mean were $(46.90 \%, 46.68 \%, 4.53 \%$ and 95.71, respectively).

\section{Vase life in distilled water (days)}

The vase life presents the $(17.20 \%, 14.58 \%$ and $9.12 \%$ ) phenotypic, genotypic and environmental coefficient of variation respectively whereas vase life exhibits the low heritability (71.88\%) and genetic advance per cent mean (25.47) compared to other traits

\section{In-situ life (days)}

The in-situ life recorded the low genetic advance as per cent mean (18.50\%), phenotypic $(11.91 \%)$ genotypic coefficient of variation $(10.34 \%)$, environmental coefficient of variation $(5.91 \%)$, heritability $(75.37 \%)$ and the in-situ life of flowers were significantly varied among the different varieties.

\section{Duration of flowering (days)}

The duration of flowering showed significant variation among the different varieties. It recorded the $(11.28 \% \mathrm{GCV}, 12.72 \% \mathrm{PCV}$, 
$5.88 \%$ ECV) and duration of flowering recorded low heritability (78.61\%) as well as low genetic advance mean was $(20.60 \%)$.

Analysis of variance showed significant differences among genotypes for all the traits studied in this experiment. Extent of variability was measured in terms of variance, genotypic co-efficient of variation (GCV), Phenotypic co-efficient of variation (PCV), Environmental coefficient variation (ECV) along with per cent heritability $\left(\mathrm{h}^{2}\right)$ and genetic advance per cent mean.

Phenotypic co-efficient of variation was higher than genotypic co- efficient of variation for all the characters, which indicates greater genotype $x$ environment interaction. The differences between the PCV and GCV were relatively very small which indicated that large amount of variability was contributed by genetic component and less by environmental influence.

In the present study, the estimates for phenotypic coefficient of variation for all the traits were higher than corresponding genotypic coefficient of variation which may be due to interaction of cultivars with the environment (Pundan and Narayan, 1993). The difference between two values i.e., PCV and GCV were quiet low which indicated that all the characters were negligibly influenced by environment.

The PCV and GCV values were high for fresh flower weight followed by flower yield per plot, flower yield per plant, number of ray florets, leaf area and stalk diameter which indicates that greater amount of variability among the different genotypes thus useful for making selections particularly based on that trait. Highest GCV and PCV were reported for number of ray florets per flower (Chobe et al., 2010). Khangjarakpam et al., (2014) also found the highest variability for the weight of flowers per plant in China aster suggesting selection of genotypes based on this trait will be effective for further improvement through breeding programmes. It indicates that these characters is most promising for selection in earlier generations, easily inheritable and can be selected by simple selection. The highest variability for leaf area and other parameters was also reported by Arulmani et al., (2016a) in Gaillardia. Similar findings were also reported by Zhang et al., (2010) in Chrysanthemum.

The characters like number of cut flowers per plot, number of cut flowers per plant, number of leaves per plant, stalk length, flower diameter, plant spread, plant height and stem thickness which indicates that moderate amount of the variability contributed by genetic component and moderate by environmental influence. Similar findings also reported by Baskaran et al., (2009) for plant height, plant spread and stem girth in chrysanthemum. (Kavitha and Auburani, 2010) found the moderate variability for plant height and stem thickness in African marigold.

Vase life, duration of flowering, days to flower bud appearance, in-situ life and days to full bloom had lowest PCV and GCV. Therefore, there exists substantial scope for the improvement and development of elite genotypes from the present studied genotypes. (Krishan and Jitendra, 2010) also reported the minimum GCV and PCV for duration of flowering in African marigold. These results are in conformity with the findings of Mathew et al., (2005) and Gourishankarayya et al., (2005) in African marigold. Baskaran et al., (2009) also reported that low variability for duration of flowering and days taken for flowering from bud initiation.

The coefficient of variation indicates only the extent of variability present in different 
characters but do not indicate their heritable portion. Burton, (1952) suggested that genotypic coefficient of variation with the help of heritability estimates would give the best picture of heritable variation. The heritability is of much importance to a plant breeder primarily as an important parameter for selection of a particular character and as index of transmissibility.

High heritability values have been found to be useful in selection of superior cultivars on the basis of phenotypic performance, while low heritability with high genetic advance is governed by additive gene effects and low heritability accompanied with low genetic advance indicates that the character is highly influenced by environmental factors and selection would be in-effective (Panse, 1957).

Heritability estimates along with genetic advance are more useful in predicting the gain under selection than heritability estimates alone.

However, it is not necessary that characters showed a high heritability will also show a high genetic advance as percent of mean. Estimates of heritability also give some idea about the gene action involved in the various polygenic traits.

Table.1 Phenotypic coefficient of variation (PCV), genotypic coefficient of

Variation (GCV), environmental coefficient of variation (ECV), heritability, and genetic advance mean per cent for 19 characters in Standard Chrysanthemum

\begin{tabular}{|l|l|c|c|c|c|c|}
\hline $\mathbf{S .}$ & Characters & $\begin{array}{l}\mathbf{G C V} \\
\mathbf{N o}\end{array}$ & $\begin{array}{l}\mathbf{P C V} \\
\mathbf{( \% )}\end{array}$ & $\begin{array}{l}\mathbf{E C V} \\
\mathbf{( \% )}\end{array}$ & $\mathbf{h}^{\mathbf{2}} \mathbf{( \% )}$ & GAM (\%) \\
\hline $\mathbf{1}$ & Plant height (cm) & 20.40 & 21.41 & 6.52 & 90.72 & 40.02 \\
\hline $\mathbf{2}$ & Plant spread (cm) & 19.89 & 21.65 & 8.55 & 84.41 & 37.64 \\
\hline $\mathbf{3}$ & No of Leaves per plant & 32.91 & 33.93 & 8.26 & 94.08 & 65.76 \\
\hline $\mathbf{4}$ & Stem thickness (cm) & 18.16 & 20.61 & 9.74 & 77.67 & 32.98 \\
\hline $\mathbf{5}$ & Leaf area (cm $\mathbf{2})$ & 46.10 & 46.83 & 8.23 & 96.91 & 93.49 \\
\hline $\mathbf{6}$ & Days to flower bud appearance & 11.82 & 12.42 & 3.84 & 90.45 & 23.15 \\
\hline $\mathbf{7}$ & Days to full bloom & 8.73 & 9.56 & 3.90 & 83.39 & 16.42 \\
\hline $\mathbf{8}$ & Number of cut flowers per plant & 33.63 & 34.34 & 6.93 & 95.93 & 67.86 \\
\hline $\mathbf{9}$ & Number of cut flowers per plot & 33.63 & 34.34 & 6.93 & 95.93 & 67.86 \\
\hline $\mathbf{1 0}$ & Fresh flower weight (g) & 69.92 & 70.25 & 6.75 & 99.08 & 143.37 \\
\hline $\mathbf{1 1}$ & Flower yield per plant (g) & 62.20 & 63.76 & 14.03 & 95.16 & 124.99 \\
\hline $\mathbf{1 2}$ & Flower yield per plot (g) & 62.20 & 63.76 & 14.03 & 95.16 & 124.99 \\
\hline $\mathbf{1 3}$ & Flower diameter (cm) & 24.61 & 25.36 & 6.14 & 94.13 & 49.18 \\
\hline $\mathbf{1 4}$ & Stalk length (cm) & 33.07 & 33.62 & 6.06 & 96.75 & 67.01 \\
\hline $\mathbf{1 5}$ & Stalk diameter (cm) & 45.99 & 46.58 & 7.41 & 97.47 & 93.53 \\
\hline $\mathbf{1 6}$ & No of ray florets & 46.68 & 46.90 & 4.53 & 99.07 & 95.71 \\
\hline $\mathbf{1 7}$ & Vase life in distilled water (days) & 14.58 & 17.20 & 9.12 & 71.88 & 25.47 \\
\hline $\mathbf{1 8}$ & In-situ life (days) & 10.34 & 11.91 & 5.91 & 75.37 & 18.50 \\
\hline $\mathbf{1 9}$ & Duration of flowering (days) & 11.28 & 12.72 & 5.88 & 78.61 & 20.60 \\
\hline & & & & & \\
\hline
\end{tabular}


Heritability estimates indicate only the effectiveness with which selection of genotype can be based on phenotypic performance, but it does not mean a high genetic advance gain. Therefore, high heritability need not always accompanied by genetic progress. Kumar (2014) suggested that the heritability value alone in predicting the resultant effect for the selecting the best individual.

Heritability (Broad Sense) estimates that in the present study were moderate to high for all the parameters studied. Characters with high heritability values are relatively less influenced by environmental effects and are effectively transmitted to progeny suggesting the use of these characters for selection.

High heritability was recorded in fresh flower weight, number of ray florets per flower, stalk diameter, stalk length, leaf area, flower yield per plant, flower yield per plot, number of cut flowers per plant, number of cut flowers per plot, flower diameter, number of leaves per plant and plant height which shows that high heritability portion of variability in these characters. Similar findings were reported by Mishra et al., (2006) in chrysanthemum and Mathew et al., (2005) in marigold. Baskaran et al., (2009) also reported the highest heritability for number of flowers per plant, stalk girth, number of ray florets per head, flower diameter and yield per plant in chrysanthemum. Highest heritability is reported in number of ray florets per head by (Zhang et al., 2010). Similar findings were also reported by Chobe et al., (2010) in gerbera and Krishan and Jitendra (2010) in African marigold.

In the present study, high heritability with high genetic advance as percent mean was reported for flower yield per plot, fresh flower weight, flower yield per plant, number of ray florets, stalk diameter, leaf area, indicating the influence of additive gene action and suggesting selection of genotypes based on these traits will be effective for further improvement through breeding programmes. Similar findings were also reported by Baskaran et al., (2009) and Kavitha and Auburani (2010). Low to moderate genetic advance as percent mean were reported in remaining characters. This indicated the ample scope for improving these traits through simple selection. Mishra et al., (2006) also reported that high heritability along with high genetic advance as percent of mean for characters like number of flowers per plant, average weight of flowers in chrysanthemum. Similar results were also reported by Mathew et al., (2005) for number of flowers per plant and flower yield in African marigold. Therefore, early success may be attained for characters having high heritability and genetic advance as percent of mean with simple selection. High heritability along with high genetic advance as percent of mean for single flower weight and flower yield was also reported by Vishnupriya et al., (2015) in African marigold.

\section{References}

Allard R.W. (1960). Principles of Plant Breeding, John Wiley and Sons Inc., London

Anonymous (1950). The Wealth of India, Raw Materials, CSIR, New Delhi. 2, 143-148

Arulmani, N., Chandrashekar, S.Y., Geeta, K., Rashmi, R., Ravi, C. H. and. Praveen, B.Y. (2016a). Studies on genetic variability in gaillardia (Gaillardia pulchella Foug.) genotypes. Res. Env. Life Sci., 9 (4): 466-469.

Baskaran, V., Jayanthi, R., Janakiram, T. and Abirami, K. (2009). Studies on genetic variability, heritability and genetic advance in chrysanthemum. Haryana $J$. Hortic. Sci., 4(2): 174-176. 
Burton, G.W. (1952). Quantitative inheritance in grasses. Proceedings of $15^{\text {th }}$ Int. Grassland Congress, 1: 227-283

Chobe, R. R., Pachankar, P. B. and Warade, S. D. (2010). Studies on genetic variability and heritability in Gerbera. The Asian J. Hort, 5(2): 356-358.

Gourishankarayya, M., Laxminarayan, H., Reddy, B. S. and Ravindra, M. (2005). Genetic variability, heritability and genetic advance in African marigold. $J$. Hort. Sci., 1(3): 37-42.

Joshi M., Verma L. R. and Masu M. M. (2010). Performance of different varieties of chrysanthemum in respect of growth, flowering and flower yield under north Gujarat condition. The Asian J. Hort. 4(2): 292-294

Johnson, H. W., Robinson, H. F. and Comstock, R. E. (1955). Estimates of genetic and environmental variability in soybean. Agron. J., 47: 314-318

Kavitha, R. and Anburani, A. (2010). Genetic variability in African marigold (Tagetes erectaL.). The Asian J. Hort, 5 (2): 344346.

Khangjarakpam, G., Kumar, R., Seetharamu., G. K., Manjunatha, R. T. and Dhananjaya, M.V. Venugopalan, R., and Padmini, K. (2014). Genetic variability for quantitative traits in China aster (Callistephus chinensis (L.) Nees), J. Hort. Sci., 9(2): 141-144.

Krishan, Pal. and Jitendra, K. (2010). Study on genetic variability, heritability and genetic advance in African marigold (Tagetes erecta L.) under Meerut region. Prog. Agric., 10(3): 144-149.

Kumar, S. (2014). Genetic variability, heritability, genetic advance and correlation for vegetative and floral characters of gerbera (Gerbera jamesonii). Int. J. Agric, Envt\&Biotech., 7(3): 527-533.

Kumar, R., (2015). Genetic variability and character association among quantitative traits in gerbera. Indian $J$. Hort., 72 (1): 88-91.

Kumari, A., Patel, K. S. and Choudhary, M. (2011). Genetic variability studies in gerbera. Res in Plant Bio., 1(5): 01-04.

Mathew, R., Beniwal, B. S., Bhatia, S. K. and Deswal, D. P. (2005). Variability and correlationstudies in African marigold (TageteserectaL.). Res. on Crops., 6 (2): 322-327.

Mishra, H. N., Das, J. N. andPalai, S. K. (2006). Genetic variability studies in spray type chrysanthemum. Orissa $J$. Hort., 34 (1): 8-12

Mode, C. J. and Robinson, H. F. (1959). Pleiotropism and genetic variance and co-Variance. Biometrics, 15: 518-537.

Nair, S. A., and Shiva, K. N. (2003). Genetic variability, correlation, and pat coefficient analysis in gerbera. J.Orna. Hort., 6(3): 180-187.

Panse, V. G. (1957). Genetics of quantitative characters in relation to plant breeding. Indian J. Genet., 17: 318-328.

Phundan, S. and Narayan, S. S. (1993). Biometrical Techniques in Plant Breeding. Kalyani Publishers, pp: 3944.

Rao, A. M. and Pratap, M. (2006). Evaluation of varieties and variability studies on chrysanthemum (Dendranthema grandiflora Tzevlev.). J. Orna. Hort., 9: 221-223.

Senapati, A. K., Prajapati, P. and Alka, S. (2013). Genetic variability and heritability studies in Gerbera (Gerbera jamesonii). African J. Agric. Res., 8(41): 5090-5092.

Singh, D. and Kumar, S. (2008). Studies on genetic variability, heritability, genetic advance and correlation in marigold. $J$. Orna. Hort., 11(1): 27-31.

Syamal, M. M. and Kumar, A. (2002). Genetic variability and correlation and correlation studies in dahlia. J. Orna. Hort., New Series, 5(1): 40-42. 
Talukdar, M. C., Mahanta, S., Sharma, B. and Das, S. (2003). Extent of genetic variation for growth and floral characters in chrysanthemum cultivars under Assam condition. J. Orna. Hort., 6(3): 201-211.

Vishnupriy, A. K., Jawaharlal, M. and Manivannan, N. (2015). Variability studies in African marigold (Tagetes erecta L.). The Bioscan, 10 (1): 407-
409.

Yuvraj and Dhatt, K. K. (2014). Studies on genetic variability, heritability and genetic advance in marigold. Indian $J$. Hort., 71(4): 592-594.

Zhang, F. F., Weimin, C. and Chen, S. (2010). Combining ability analysis on ornamental characters of chrysanthemum. J. Zhejiang Forestry College., 2(1): 10-14.

\section{How to cite this article:}

Sushma Patil, Kamal Kishor Nagar and Sumana, D.A. 2019. Variability, Heritability and Genetic Advance in Chrysanthemum (Chrysanthemum morifolium Ramat.) under Ecological Conditions of Sub-Humid Zone of Rajasthan. Int.J.Curr.Microbiol.App.Sci. 8(02): 1774-1782. doi: https://doi.org/10.20546/ijcmas.2019.802.209 